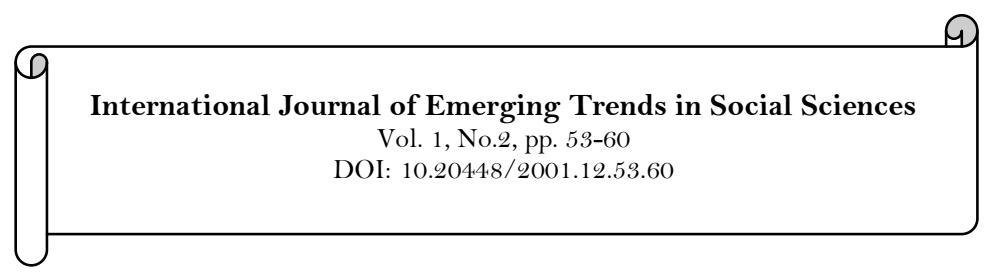

\title{
Reflections on Decentralization, Community Empowerment and Sustainable Development in Cameroon
}

\author{
Jude Ndzifon Kimengsi ${ }^{1}$ \\ Solange Akhere Gwan² \\ ${ }^{1}$ Department of Geography \& Planning, University of Bamenda, Cameroon. \\ ${ }^{2}$ Department of Sociology and Human Geography, University of Oslo, Norway.
}

\begin{tabular}{|c|c|}
\hline Abstract & \\
\hline $\begin{array}{l}\text { Good governance and development discussions shed light on the role } \\
\text { of citizen participation as a fundamental mechanism of achieving } \\
\text { sustainable development in local communities. The current } \\
\text { popularity of decentralization, especially in the developing world, is } \\
\text { unparalleled, with } 80 \% \text { of all developing and transition countries } \\
\text { undertaking some form of decentralization over the past two } \\
\text { decades. As of July 2004, the Cameroonian house of parliament } \\
\text { promulgated into law, three bills on decentralization. Under the } \\
\text { provisions of the laws of } 2004 \text {, there is the devolution of powers } \\
\text { accompanied by the transfer of means (financial, material and } \\
\text { human), to local councils. This move to decentralize power, authority } \\
\text { and resources is seen as a logical way forward to bring development } \\
\text { closer to the people not only in terms of actions, but also in terms of } \\
\text { their development choices. Although emphasis is placed on the need } \\
\text { for communities to achieve sustainable development, the role of } \\
\text { decentralization is primordial. This paper posits that } \\
\text { decentralization, if effectively implemented, could serve as a panacea } \\
\text { to the sustainable development impasse of local communities in } \\
\text { Cameroon. It holds that a highly inappreciable level of } \\
\text { decentralization that characterizes the Cameroon society has been } \\
\text { the bulwark to sustainable development of communities. The paper } \\
\text { recommends the need to speed-up the process of decentralization by } \\
\text { undertaken effectively reforms and creating timelines for targets } \\
\text { towards decentralization and sustainable community development } \\
\text { through empowerment. }\end{array}$ & $\begin{array}{l}\text { Keywords: } \\
\text { Decentralization } \\
\text { Community empowerment } \\
\text { Sustainable development } \\
\text { Cameroon. } \\
\text { Licensed: } \\
\text { This work is licensed under a } \\
\text { Creative Commons Attribution } \\
\text { 4.O License. }\end{array}$ \\
\hline
\end{tabular}

\section{Introduction}

Discourse on good governance, democracy and development continues to shed light on the need to encourage citizen participation as a fundamental mechanism of local capacity building (empowerment) for sustainable development in local communities. These mechanisms can effectively function in systems where decentralization is effective. Decentralization entails the transfer of power, responsibilities and resources from the central government to sub-national levels of government at provincial and/or local levels. It is essentially a political process, involving the redistribution of power and resources (Kum, 2011). Those who have to give up power and resources - in this case central governments-will often, naturally, be reluctant to give it. Most of the benefits of decentralization are believed to arise from increased participation. It is a process which, if rigorously applied, especially in the allocation of resources, will likely enhance community development.

Existing theoretical constructs contends that decentralisation, a process through which powers, responsibilities and resources are devolved by the central state to lower territorial entities and regionally/locally elected bodies, increases efficiency, participation, equity, and environmental sustainability. In the circumstances therefore, many forms of decentralisation have been implemented in Africa since the colonial period, with varying degrees of success (Oyono, 2004).

The current popularity of decentralization, especially in the developing world, is unparalleled, with $80 \%$ of all developing and transition countries undertaking some form of decentralization over the past two decades (International Council for Human Rights Policy (ICHRP), 2005). It is believed that this new wave of 
decentralization if properly handled could be of much relief to the rural population especially in their strive towards integrated rural development. Perhaps, the ideas of Goldman (1998) could be solicited which points to the fact that:

"Decentralization appeared to offer a locus for integrated rural development, and institutions to deal with it (local government) and the potential for downsizing central government and promoting good governance" (Dalal-Clayton, Dent, \& Dubois, 2003).

As of July 2004, the Cameroonian house of parliament promulgated into law, three bills on decentralization. Under the provisions of the laws of $2004^{1}$, there is the devolution of powers accompanied by the transfer of means (financial, material and human), to local councils in all 10 regions of Cameroon. This move to decentralize power, authority and resources is seen as a logical way forward to bring development closer to the people not only in terms of actions, but also in terms of their development choices (Kum, 2011).

Empowerment as a concept is, however, not easy to define because of its extremely variable meaning which is influenced by social contexts, individual conditions and political circumstances (Quagliariello, 2009). It can be looked upon as a key for quality of life and human dignity, good governance, pro-poor growth, project effectiveness, and improved service delivery (Allahdadi, 2011). In terms of citizen inclusion at the local level, empowerment and participation can help to ensure that basic services reach poor people, and can lower operation and maintenance costs by comparison with centrally managed activities (World Bank, 2002). Empowerment refers to the expansion in people's ability to make strategic life choices in a context where this ability was previously denied to them (Naila, 2001).

The notion of empowerment has evolved within the development discourse to emphasize the need to build capacity in societies to respond to the challenges of their political and economic environment. Citizen participation does not necessarily lead to empowerment. Empowerment is to a situation where people can 'participate' in a project, but without having the power to make decisions on the critical issues affecting the project. Empowerment, as Narayan (2002) contends, requires a process through which people's freedom of choice and action is expanded to enable people to have more control over resources and decisions that affect them. For empowerment to happen, participation must, therefore, be effective in a way that it can enforce accountability and changes in behavior within the relevant government bureaucracies, and ensure changes that make participation more inclusive of the poor and the underprivileged (Crook, 2003). Empowerment relates to the expansion of assets and capabilities of communities to participate in, negotiate with, influence, control, and hold accountable institutions that affect their lives (World Bank, 2002). This involvement of communities in the decision process can be done in several stages within a spectrum ranging from a very passive role to a very active impact of communities in decision-making. Furthermore, community empowerment spreads from a powerless level up to a powerful one (Community Empowerment Working Group, 2003).

Community empowerment which is an essential precondition for effective decentralization is viewed from the perspective of achievements in human development, arising from citizen participation and representation which translate to shared benefits for local communities. This represents a necessary condition for effective decentralization and sustainable development in Cameroonian communities. Whereas some powers and functions have been devolved to local governments, the cardinal goals of decentralization seem to be elusive, whereby there is less support of the community's role in raising resources for local development, demanding accountability from their leaders, participating in planning, and choosing their leaders without manipulation from the local 'elite' at the time of elections (Kakumba, 2010).

Sustainable development as presented by the Brundtland report relates to meeting the needs of the present generation without compromising the ability to meet the needs of the future generations (World Commission on Environment and Development, 1987 cited in Wilbanks (1994). Achieving sustainable development requires a measure of local initiative and power to administer programmes (Taylor \& Mackenzie, 1992). In this regard, Blackwell, Goodwill, and Webb (1991) emphasized the role of government policy in ensuring sustainable development. While they acknowledge the contribution of expertise, they maintained that for better local development of communities, appropriate technology can only be gained if the foreign experts do not assume that they "know" the local conditions. Technologies that are commensurate to the development sought, feasible and affordable should be introduced. Hence, simple, failsafe systems should be introduced. This is necessary as it will take care of the resources present in the region. From a contrasting position, Latouche (2003) views sustainable development as a paradox by noting that the problem with sustainable development is not so much about the word "sustainable" (it can even sound rather nice) as that of "development". The association is explosive. Sustainable development implies that human activity does not have to create a pollution rate that is superior to the capacity to regenerate the environment. He concluded that sustainable development is an oxymoron, a victim of its own contradictions, of its failures, due to its unsustainable character, or from the exhaustion of the natural resources. This paper contends that decentralization, if effectively implemented, could serve as a panacea to the sustainable development impasse of local communities in Cameroon.

\footnotetext{
${ }^{1}$ Bill No 762/PJL/AN on the Orientation of Decentralization No 51/AN Explanatory (June 2004), National Assembly, $7^{\text {th }}$ Legislative Period Legislative Year 2004, $2^{\text {nd }}$ Ordinary Session.
} 


\section{The Problem}

While many African nations have undertaken substantive reforms through decentralization to promote good governance and development, there is increasing difficulty in translating the reform initiatives into specific operations to support effective local planning, capital investment, budgeting and financial management, revenue and resource mobilization, and production (Crook, 2003; Olowu, 2003; Wunsch, 2001). The major reasons for this difficulty, according to Wunsch (2001) are a combination of central governments' reluctance to relinquish authority in these key areas and the complexity of organizational redesign to support decentralization. Through decentralization, government comes closer to the people to enable local representation of all sorts of constituencies - minorities, women, youth, small-scale farmers and businessmen, who get elected onto local councils; this kind of representation is a key element in empowerment, which is defined as a significant voice of the marginal constituencies in public policy decisions that affect their livelihoods (Blair, 2000). Local policy decisions reflecting this empowerment would then serve the minority groups by providing them with more appropriate infrastructure, better living conditions, and enhanced economic growth (Blair, 2000). The improvements could then spur poverty reduction, enhance equity among groups, and lead to sustainable development. It is widely documented that decentralisation increases efficiency, participation, equity, and environmental sustainability. This explains why the concept became a much sought after concept for development with varying degrees of success across Africa. This move to decentralize power, authority and resources is seen as a logical way forward to bring development closer to the people not only in terms of actions, but also in terms of their development choices. Although emphasis is placed on the need for communities to achieve sustainable development, the role of decentralization in this regard is primordial. This paper holds that decentralization, if effectively implemented, could serve as a panacea to the sustainable development impasse of local communities in Cameroon Figure 1. It holds that a highly inappreciable level of decentralization that characterizes the Cameroon society has been the bulwark to sustainable development of communities.

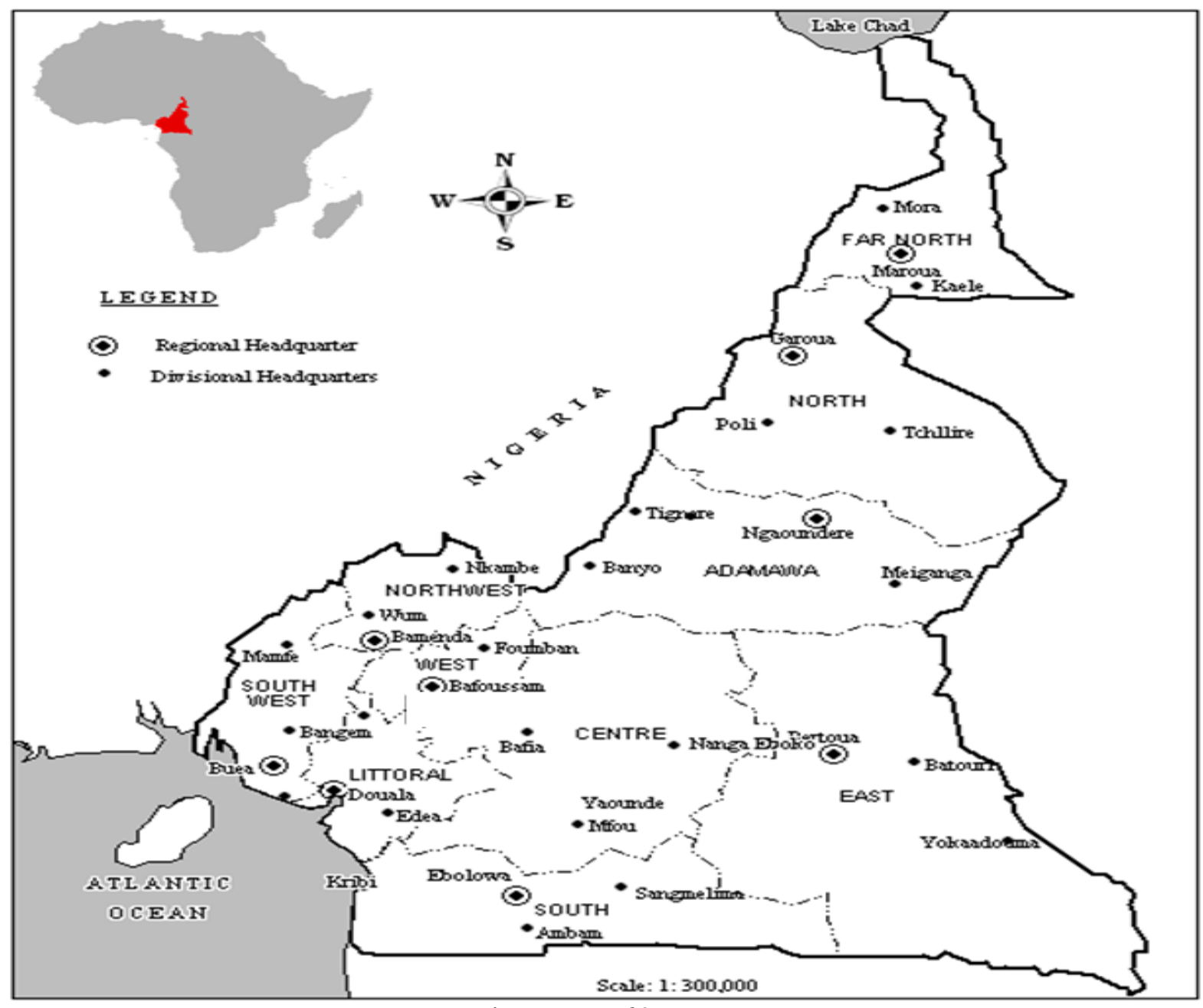

Source: Adapted from Neba (1999).

Figure-1. Map of Cameroon. 


\section{Methodology}

This study employed a participatory dialogue approach within some councils to assess their levels of capacity building and identify some of their present constraints. Focus groups discussions (FGDs) were conducted with key stakeholder groups, representatives of the central authorities, council representatives and the local population of the councils concerned. The focus group discussions presented a platform to x-ray the stance of these stakeholder groups for sound recommendations to be put forth to improve on the benefits of decentralization in Cameroon. Apart from obtaining information through FGDs and the administration of questionnaires, interviews will also be conducted to some authorities while field visits will be made to the council concerned. The information generated from this source will be complemented by secondary data from government texts on decentralization and council reports which cover issues of decentralization. In addition the road map for development which has been prepared by the government will also be consulted to identify possible avenues where a much effective decentralization platform can assist the nation to emerge by 2035 . The rationale behind such a method is that it will give room for clarification on certain issues which might seem obscured to the stakeholders concerned. In this connection, two months will be allocated for weekly broadcasting through different media, both local and national for better spread of the information.

\subsection{Decentralization and Sustainable Development Perspectives in Cameroon}

An important democratic outcome that is expected from the process of decentralization is improved accountability and responsiveness to increased numbers of citizens through the creation of sub-national jurisdictions. Local governments with delegated and devolved powers and authorities respond to issues of direct concern to their constituents. These sub-national jurisdictions essentially create shorter routes to accountability when compared with citizen connections to national government (Worlds Bank, 2004). This is however, largely dependent on community empowerment through education, training and information diffusion (Olken, 2005). Decentralization is therefore seen as a tool for quality service provision especially through the provision of opportunities for greater innovation at the local level, and through the demonstration effect, whereby other jurisdictions imitate the innovations and spread better practices to other localities (Oates, 1999). This is linked to experimental federalism - a concept which holds that decentralization encourages a few brave municipalities to adopt reforms and then successful reforms are adopted by other localities (Oates, 1999).

The ultimate goal of decentralisation is to bring the government closer to the people and thereby involve them more actively in the process of development. It furthers popular participation (Midgley, 1986, cited in Cheka (2007)). However, doubts are expressed with respect to the fact that decentralisation may not contribute to sustainable development since it does not effectively engender participation of the masses in development (Totté et al., 2003 cited in Cheka (2007)). Some theorists view decentralisation as a means of promoting sustainable development through combating corruption and alleviating poverty; considering that decentralisation provide avenues for participatory management and better use of available resources (Wunsch et al., 1990, Cheema et al. 1983 cited in Cheka (2007)). Authors have argued that there is a need for better organisation and coordination of interventions of the stakeholders. The process of decentralization is currently hampered by especially financial constraints on local authorities and limited capacities of the actors and beneficiaries of devolved powers. What is more? The need to strengthen the capacities of all stakeholders through an approach that is sustainable is necessary if the objectives of decentralization are to be met (Cheka, 2007).

The government of Cameroon views decentralization to involve the devolution by the State of special powers and appropriate resources to regional and local authorities which constitute the basic driving force for promotion of development, democracy and good governance at the local level. The 2004 Bill on the orientation of the decentralization process provides a number of essential objectives to include enabling concerned inhabitants to become resolutely involved in defining and managing affairs of their regional and local authorities, fostering and promoting the harmonious development of regional and local authorities on the basis of national solidarity, regional potential and inter-regional balance, and to place Cameroon in line with constitutional and international requirements in the area of decentralization (Cheka, 2007). The bill presents 4 (four) major parts as follows, the principle of devolution powers (which lays down the procedure under which resources are devolved to the local and regional authorities for their socio-economic welfare); the organization and functioning of regional and local authorities (defines the functional mechanisms of the recipient authorities); supervision of regional and local authorities (which indicates the central authorities and constituted bodies which supervise the institutions); and monitoring organs of the decentralization process indicating the bodies in charge of supervision (Cheka, 2007). 
Table-1. Types of Decentralization and Impacts on Local Governments (LG).

\begin{tabular}{|c|c|c|c|}
\hline & Administrative & Financial / Fiscal & Political \\
\hline Deconcentration & $\begin{array}{l}\text { LG follows central policies, } \\
\text { plans according to central } \\
\text { norms. Form \& structure of } \\
\text { LG centrally determined. LG } \\
\text { staff are employees of central } \\
\text { ministries, accountable to } \\
\text { center. LG is service delivery } \\
\text { arm of center, little or no } \\
\text { discretion in service choice or } \\
\text { mix, modes of provision. LG } \\
\text { provides information } \\
\text { upwards to center }\end{array}$ & 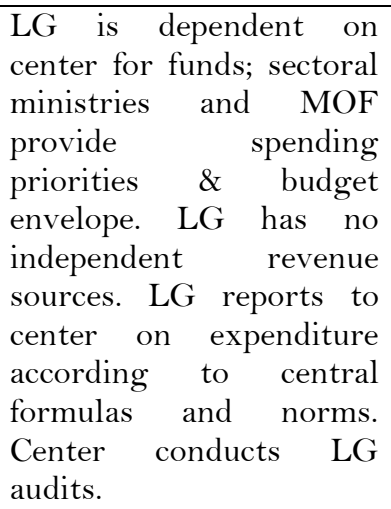 & $\begin{array}{l}\text { No elected LG, officials } \\
\text { appointed by center, \& } \\
\text { serve central interests. } \\
\text { Civil society \& citizens } \\
\text { rely on remote \& weak } \\
\text { links to central } \\
\text { government for } \\
\text { exercising } \\
\text { accountability. Little } \\
\text { political space for local } \\
\text { civil society, central } \\
\text { elites control politics. }\end{array}$ \\
\hline Delegation & $\begin{array}{l}\text { LG follows central policies \& } \\
\text { norms, has some discretion to } \\
\text { tailor to local needs, \& to } \\
\text { modify form \& structure. LG } \\
\text { staff may be mix of central } \\
\text { and LG employees; LG has } \\
\text { authority on hiring \& } \\
\text { placement; center handles } \\
\text { promotion \& firing. LG } \\
\text { provides service menu set by } \\
\text { center, some discretion in } \\
\text { mix to fit local needs, \& in } \\
\text { modes of provision. LG } \\
\text { provides most information } \\
\text { upwards to center \& selected } \\
\text { information to local officials, } \\
\text { citizens. }\end{array}$ & $\begin{array}{l}\text { LG is dependent on } \\
\text { center for funds; LG has } \\
\text { some discretion on } \\
\text { spending priorities within } \\
\text { budget envelope. Block } \\
\text { grants \& conditional } \\
\text { transfers from center } \\
\text { offer some autonomy. LG } \\
\text { has no independent } \\
\text { revenue sources. LG } \\
\text { reports to center and } \\
\text { local officials on } \\
\text { expenditure according to } \\
\text { central formulas and } \\
\text { norms. Center and LG } \\
\text { conducts LG audits. }\end{array}$ & 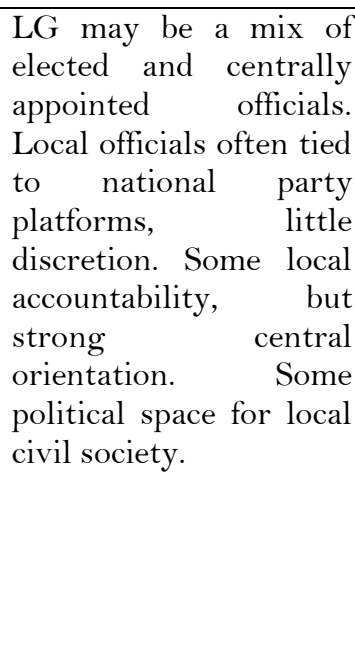 \\
\hline Devo & $\begin{array}{l}\text { LG is subject to national } \\
\text { norms, but sets local policies } \\
\& \text { priorities, plans } \\
\text { autonomously in response to } \\
\text { local preferences \& needs. LG } \\
\text { determines own form \& } \\
\text { structure. LG staff are } \\
\text { employees of LG, which sets } \\
\text { salaries, numbers, } \\
\text { assignments, \& handles } \\
\text { hiring/firing. LG determines } \\
\text { service mix, modes of } \\
\text { provision, eligibility, \& } \\
\text { allocation. LG provides } \\
\text { information to local officials, } \\
\text { citizens. }\end{array}$ & $\begin{array}{l}\text { LG sets spending } \\
\text { priorities, plans how to } \\
\text { meet service delivery } \\
\text { obligations given } \\
\text { resource availability. LG } \\
\text { has mix of own-source } \\
\text { revenues, revenue- } \\
\text { sharing, central transfers. } \\
\text { LG may have some } \\
\text { authority for debt } \\
\text { financing, but is subject } \\
\text { to a hard budget } \\
\text { constraint. LG reports to } \\
\text { local officials and citizens } \\
\text { on expenditure according } \\
\text { to central formulas and } \\
\text { norms. LG is responsible } \\
\text { for audits, reports results } \\
\text { locally and to center }\end{array}$ & $\begin{array}{l}\text { Locally elected officials } \\
\text { lead LG, may or may } \\
\text { not be linked to } \\
\text { national parties, } \\
\text { platforms respond to } \\
\text { constituent demands } \\
\text { and needs. Strong local } \\
\text { accountability, LG } \\
\text { shapes budget } \\
\text { priorities, investments, } \\
\text { service mix to fit local } \\
\text { preferences and needs. } \\
\text { Broad political space for } \\
\text { local civil society. }\end{array}$ \\
\hline
\end{tabular}

Source: (Brinkerhoff \& Azfar, 2006; Johnson, 1995; Worlds Bank, 2004).

An illustration of the benefits of decentralization can be seen in the trails fashioned by a number of projects conceived in Cameroon within the framework of the National Poverty Reduction Strategy (NPRS). The major ones are the National Participatory Development Programme (PNDP), the Rumpi Project and the Grassfield Participatory and Decentralized Rural Development Project (GP-DERUDEP). These missions have decentralized various public services with the objective of alleviating poverty at the grassroots through aspects like agricultural and pastoral development, environment, water and forests, agronomic research, the protection of civil society, capacity building and rural development (Kimengsi \& Fombe, 2015). While decentralization has a number of positive outcomes, it is evident that much still needs to be done by the government of Cameroon to ensure success in this process. 
Community capacity deficiencies stand as the bane towards the achievement of participatory empowered governance. This is however not a rule because there are varied cases where the positive role of government/community interaction in service delivery has been successful, while in others, it has not (Evans, 1996). Therefore a missing ingredient could be competent and engaging public institutions (Heller, 2001). This perhaps explains why Goal 16 of the Sustainable Development Goals (SDGs) stresses on the need to "promote peaceful and inclusive societies for sustainable development, provide access to justice for all and build effective, accountable and inclusive institutions at all levels." In a related dimension, Heller (2001) argues that the capacities of citizens to engage the state, ....are constructed both from below - through particular patterns and trajectories of mobilization-and from above, in the artifactuality of group formation, that is, the ways in which states create and structure channels, opportunities, and incentives (or disincentives) for collective action. Citizen capacities are as such highly malleable and forged in and through state-society engagements. Heller's characterization of the dynamic and emergent nature of empowerment capacity indicates the need to look beyond one-time assessments of experience with community empowerment. If elites capture the mechanisms and the benefits of community empowerment at a particular point in time, it does not necessarily mean that it will happen all the time (Heller, 2001).

As Cameroon strives towards emergence as spelt out in Vision 2035, it is important to remark that a move towards effective community empowerment for decentralization is seen as a necessary ingredient; local communities will be fully prepared and empowered to take up the task and decide on their development directions. However a major challenge in this present dispensation remains the fact that the whole process of decentralization still remains selective, as central authorities continue to hold firmly on power. This situation limits the possibilities for councils to fully take charge of their development - it leads to a somewhat disjointed developmental actions. Another challenge is the fact that it seems that the government took the second step before the first. This could be explained by the fact that communities still suffer from the problem of low capacity building and inadequate trained personnel who can fully handle issues of decentralization. In the circumstances therefore, it would seem that local councils are seemingly not ripe enough to embrace and fully manage the authority and resources that go with decentralization. Perhaps, this is one of the reasons why the whole process of devolving powers is still incomplete. There is a need to identify some of the challenges confronting both central authorities and the local councils as the process of transferring power and resources unfolds. Decentralization should logically give a free hand to all the local authorities, that is, autonomy to these local areas so as to develop their resources and ensure the development of the areas. Local authorities should bring local people into the decision-making process and establish mechanisms to integrate their knowledge, needs, and aspirations. It is important to note that communities can successfully handle their resources should they be empowered adequately and trained to fully manage their affairs. It has been observed that even the role/job description of councillors for instance, are unclear and the councillors themselves are ignorant of their rights and obligations in this process.

It should be borne in mind that community empowerment is a long-term process that takes place over years, building on the collective experience and skills of gradually expanding groups of citizens. For instance, the experience of success in coproduction also encourages citizens to develop other horizontal relationships and social capital. In addition, once the forces of community empowerment are set in motion through particular activities, the broadened demand for transparency and accountability makes it more difficult for public officials to revert to former behaviours (Ostrom, Schroeder, \& Wynne). The Indian right-to-information movement represents a relevant example as it illustrates the tenacity and persistence of local groups in carving out empowered space and forcing a response from power-holders Goetz and Jenkins (2001), Ackerman (2004).

\section{Conclusion}

So far, the multiplicity of interpretations and context on decentralization, community empowerment and sustainable development limits scientific ability to conclude on the links between these concepts. This equally applies to making conclusive statements regarding the relationship between community empowerment, decentralization, and outcomes relating to democratic deepening and service delivery effectiveness (Brinkerhoff \& Leighton, 2002). While it is clear that the potential for community empowerment to contribute to democratization and service delivery effectiveness at community level depends upon the extent to which a country's governance structure tends toward the devolutionary end of the decentralization continuum, the existence of a legal and institutional framework, in and of itself, is insufficient (Brinkerhoff \& Leighton, 2002). As many studies of decentralization conclude, in a substantial number of countries, existing decentralization laws, institutions, and procedures are incompletely and often weakly implemented, creating an institutional "limbo" where decentralized local government suffers from incoherence, hazy accountability, and poor performance (Brinkerhoff \& Leighton, 2002; Crook, 2003; McNulty, 2006).

The call for the local people to participate in development means that they must be empowered and schooled. This implies that human resource development has to be given a pride of place in the drive towards empowering the local population. An important ingredient to the economic takeoff of a region is its level of development in technical and vocational training. Technical and vocational training gives room for the 
utilization of the acquired technology for the harnessing of natural resources for eventual economic growth. Since the level of technical development is still far behind vis-à-vis general education, it is recommended that more of these institutions that are involved with technical work should be encouraged. In other words, the budgetary allocation for education for most regions in Cameroon should be skewed towards technical and vocational education.

In this new wave of decentralization which seems to herald glad tidings, it is necessary to recommend that the government should try as much as possible to speed up this process and make it more efficient, transparent and properly managed. Giving the local authorities the mandate and resources at their disposal to run the affairs of their areas is a positive step towards strategic development for most regions in Cameroon.

For decentralization to succeed, stakeholders (councillors and the local population, among others) must be empowered so that they can clearly define their functions since it seems that most councillors who are supposed to serve as "watch dogs" against the mismanagement and misappropriation of budgets by Municipal authorities and Members of Parliament are yet to fully understand their role in this process. The hitherto situation of allowing these authorities to decipher in most cases what must be obtained and even go scot free for mishandling resources geared toward development must be brought to a halt by these watch dogs. It is however recommended that the pace of decentralization be hastened so that the local people can be schooled and empowered on the challenges that lie ahead as far as local autonomy is concerned. This is very crucial for development to be achieved. Without such ground works, decentralization may just give resources to people who will continue to swell their accounts with no meaningful community development to show for.

Given that the government's vision in promoting sustainable development in communities is hampered by the problem of ineffective monitoring mechanisms, it will be necessary to recommend the implantation of monitoring teams who get to the field and carry out an effective survey of projects before and after they are executed so as to avoid the misdirection of resources.

\section{References}

Ackerman, J. (2004). Co-governance for accountability: Beyond "exit" and "voice". World Development, 32(3), 447-463.

Allahdadi, F. (2011). Towards women's empowerment and poverty reduction in Iran. Life Science Journal, 8(2), $213-216$.

Blackwell, J. M., Goodwill, R. N., \& Webb, R. (1991). Environment and development in Africa: Selected case studies. EDI Development Policy Case Series, Analytical Case Studies, Number 6, EDI of the World Bank/IBRD. Washington DC: World Bank.

Blair, H. (2000). Participation and accountability at the periphery: Democratic local governance in six countries. World Development, 28(1), 21-39.

Brinkerhoff, D., \& Azfar, O. (2006). Decentralization and community empowerment: Does community empowerment deepen democracy and improve service delivery? Paper presented at the Paper Prepared for: U.S. Agency for International Development Office of Democracy and Governance, October 2006.

Brinkerhoff, D., \& Leighton, C. (2002). Decentralization and Health System Reform: Issue in Brief. Washington, DC: U.S. Agency for International Development. Partners for Health Reformplus Project. Insights for Implementers.

Cheka, C. (2007). The state of the process of decentralisation in Cameroon. Africa Development, 32(2), 181-196.

Community Empowerment Working Group. (2003). Defining community empowerment.

Crook, R. C. (2003). Decentralisation and poverty reduction in Africa: The politics of local-central relations. Public Administration and Development: The International Journal of Management Research and Practice, 23(1), 77-88.

Dalal-Clayton, B., Dent, D., \& Dubois, O. (2003). Rural planning in developing countries: Supporting natural resource management and sustainable livelihoods. London: Earthscan Publishing Ltd.

Evans, P. (1996). Government action, social capital and development: Reviewing the evidence on synergy. World Development, 24(6), 1119-1132.

Goetz, A. M., \& Jenkins, R. (2001). Hybrid forms of accountability: Citizen engagement in institutions of public-sector oversight in India. Public Management Review, 3(3), 363-383.

Goldman, I. (1998). Decentralisation and sustainable rural livelihoods. In: D Carney (Ed) sustainable rural livelihoods: What contribution can we make? Paper presented at the Papers Presented at the Department for International Development's Natural Resource Advisers' Conference, July. Department for International Development, London.

Heller, P. (2001). Moving the state: The politics of democratic decentralization in Kerala, South Africa, and Porto Alegre. Politics \& Society, 29(1), 131-163.

International Council for Human Rights Policy (ICHRP). (2005). Local government and human rights: Doing good service. Geneva: International Council on Human Rights Policy.

Johnson, R. (1995). Decentralization strategy design: Complementary perspectives on a common theme. Washington, DC: US Agency for International Development, Implementing Policy Change Project.

Kakumba, U. (2010). Local government citizen participation and rural development: Reflections on Uganda's decentralization system. International Review of Administrative Sciences, 76(1), 171-186.

Kimengsi, J. N., \& Fombe, L. F. (2015). The growth pole strategy as a panacea for Sub-Saharan Africa's regional development challenges: Reflections from Cameroon and Nigeria. Journal of Sustainable Development in Africa, $17(8), 79-89$.

Kum, N. V. (2011). The relevance of indigenous core cultural values to decentralization in Cameroon: The case of traditional chieftaincy. African Journal of Social Sciences, 2(3), 136-158.

Latouche, S. (2003). Sustainable development as a paradox. economist, university of Paris. 
McNulty, S. L. (2006). Empowering civil society: Decentralizing the state and increasing local participation in Peru. Unpublished Ph.D. Dissertation, George Washington University, Department of Political Science, Washington, DC.

Naila, K. (2001). Reflections on the measurement of women's empowerment. In l, 2001, Ida Studies No. 3. Novum Grafiska AB: Stockholm.

Narayan, D. (2002). Empowerment and poverty reduction: A sourcebook. Washington, DC: World Bank.

Neba, A. S. (1999). Modern geography of the republic of Cameroon (3rd ed.). Bamenda: Neba Publishers.

Oates, W. E. (1999). An essay on fiscal federalism. Journal of Economic Literature, 37(3), 1120-1 149.

Olken, B. A. (2005). Monitoring corruption: Evidence from a field experiment in Indonesia. Cambridge, MA: National Bureau of Economic Research, Working Paper 11753.

Olowu, D. (2003). Local institutional and political structures and processes: recent experience in Africa. Public Administration and Development: The International Journal of Management Research and Practice, 23(1), 41-52.

Ostrom, E., Schroeder, L., \& Wynne, S. Institutional incentives and sustainable development. Boulder, Co: Westview Press.

Oyono, P. R. (2004). One step forward, two steps back? Paradoxes of natural resources management decentralisation in Cameroon. The Journal of Modern African Studies, 42(1), 91-111.

Quagliariello, R. (2009). The importance of gender empowerment in rural development program GEWAMED and TERCOM projects. Mediterranean Agronomic Institute of Bari-IAMB.

Taylor, D. R., \& Mackenzie, F. (1992). Development from within: Survival in rural Africa.

Wilbanks, T. J. (1994). "Sustainable development" in geographic perspective. Annals of the Association of American Geographers, 84(4), 541-556.

World Bank. (2002). Empowerment and poverty reduction: A sourcebook. written by Deepa Narayan, poverty reduction and economic management (PREM). . Washington, D.C: World Bank.

Worlds Bank. (2004). World development report 2004: Making services work for the poor. Washington, DC: World Bank.

Wunsch, S. J. (2001). Decentralization, local governance and recentralization' in Africa. Public Administration and Development(21), 277-288. 